\title{
A magyar mezőgazdasági vállalatok jövedelmezőségének vizsgálata*
}

\section{fóró Jenő,}

a Budapesti Müszaki és Gazdaságtudományi Egyetem hallgatója

E-mail: farojeno96@gmail.com

\section{Hojdu Ottó,}

az MTA doktora,

az Eötvös Loránd Tudományegyetem, Neumann János Egyetem egyetemi tanára

E-mail: hajdu@gti.elte.hu
A tanulmány fó célja bemutatni azt, hogy alapvetően mely pénzügyi-számviteli indikátorokkal érdemes leírni a vállalati jövedelmezőség alapvető tényezőit a magyar mezőgazdaságban, majd egy új megközelítést javasolni ezen indikátorok mérésére, szürésére, és egy paneljellegü adatállomány alapján becsülni, valamint tesztelni a ,panelhatásokat”. A panel-adatállomány időbeli strukturális törése lehetővé teszi, hogy a jövedelmezőséget magyarázó $X$ regresszorváltozók időben „tört” hatása is kirajzolódjon. A jövedelmezőség célváltozó indikátora, a ROA-mutató (return on assets - eszközarányos nyereség) modellezése azon eredményre vezet, hogy a jövedelmezőség szintjét emeli az eszközszerkezet eltolódása a forgóeszközök irányába, az eszközök hatékony müködtetése, illetve hosszú távon külső források bevonása. Egyes regresszorok időben késleltetve fejtik ki hatásukat. A tanulmány új megközelítést alkalmaz, miszerint egy közgazdasági hipotézisekből induló ún. full modellt nem automatikus szelektáló algoritmus által, hanem szakmai úton szükít. Az $X$ regresszorok strukturálisan tört kvadratikus és logaritmikus hatásai is szerepelnek a modellben. $\mathrm{Az}$ alkalmazandó regresszorok megadására, kiszürésére egy rendhagyó, új panelmódszert javasolnak a szerzők.

TÁRGYSZÓ:

Jövedelmezöség.

Mezőgazdaság.

DOI: $10.20311 /$ stat2018.08-09.hu0818

* A cikk az Emberi Erőforrások Minisztériuma ÚNKP-17-1-I-BME-305 számú Új Nemzeti Kiválóság Programjának támogatásával készült. 
A jövedelmezőség és az azt befolyásoló tényezők közötti kapcsolat feltárása alapvetően fontos az üzleti vállalkozások működése szempontjából: egy jövedelmező vállalat könnyebben jut beruházási forrásokhoz. A jövedelmezőséget meghatározó tényezők azonosítása céljából számos tanulmány készült, amelyek empirikus adatállományokon jellemzően standard szelekciós statisztikai módszertant alkalmaztak eredményeik alátámasztása érdekében.

A tanulmányban bemutatjuk a jövedelmezőségre vonatkozó elméleteket és az elméletek igazolása érdekében tett kísérleteket. Célunk:

- a hazai mezőgazdasági adatállomány alapján a vállalkozások jövedelmezőségére ható releváns változók marginális hatását vizsgálni;

- a releváns változók szelektálását elsősorban közgazdaságiszakmai megfontolások alapján végezni, majd statisztikai hipotézisvizsgálati tesztek alapján finomítani;

- javaslatot tenni egy új változószelekciós eljárás alkalmazására a jövedelmezőségi regresszorok körében.

A szelektálás alapjául szolgáló változók körét nagyrészt standard mérlegelemzési, pénzügyi mutatók alkotják, melyek egy részének éven túl érvényesülő jövedelmezőségi hatást tulajdonítunk. Azért, hogy az éven túli jövedelmezőségi hatásokat is tanulmányozhassuk, kialakítjuk a változók késleltetési struktúráját közgazdasági megfontolásokra támaszkodva. A jövedelmezőséget befolyásoló változók kiszürése érdekében új megközelítést alkalmazunk, melyben egy speciális panelmodellbe illesztjük a jövedelmezőséggel összefüggőnek feltételezett változókat, hogy közülük - parametrikus és nemparametrikus trendszürést együttesen alkalmazva, a változók elhagyása során a $p$-érték és a szakmai relevancia kombinációjára helyezve a hangsúlyt szelektáljuk a jövedelmezőséget befolyásoló releváns változókat. Az ezek évről évre változó parciális hatását a magyar mezőgazdaság 1312 elemű mintájából becsüljük. A hatások abszolút nagysága és iránya alapján következtetéseinket - arra vonatkozóan, hogy miért esett vissza 2009-2010-ben a nyereségesség, illetve miként javítható a vállalati jövedelmezöség - összevetjük a szakirodalom eddigi eredményeivel, mind az egyezésekben (idegen töke aránya (Lazăr [2016]), árbevételleszközök (DencicMihajlov [2014])), mind az eltérésekben (méret (Pratheepan [2014])). A nem szignifikáns, de pénzügyileg relevánsnak tartott együtthatókra külön felhívjuk az Olvasó figyelmét! 


\section{Irodalmi áttekintés}

A vállalati teljesítmény régóta képezi kutatások tárgyát a közgazdaságtudományok területén. A jövedelmezőségi kutatások gyakori eszköze a regresszióanalízis, melynek során a felhasznált változók alapján jól elkülöníthető iskolák alakultak ki. Az így létrejövő elméleti keretrendszerek adekvát mivoltát számos szerző igyekezett alátámasztani empirikus kutatásokkal. Ebben a fejezetben az elméletek történeti fejlődésén kívül bemutatjuk, hogy az empirikus teszteken miként „vizsgáztak” az egyes modellek.

A neoklasszikus közgazdászok tökéletes versenyre vonatkozó - rendkívül szigorú feltételrendszerrel leírható - elméletében nincs helye a profitok közötti különbségeknek, ugyanis adott a gyors be- és kilépés lehetősége, amely feltétel lehetővé teszi, hogy a vállalatok rövid távú profitja, a fokozatos belépések miatt lenullázódjon, a veszteségek pedig a kilépések eredményeképp megemelkedő árak miatt tünnek el, zérus profitot eredményezve a piacon tevékenykedő vállalatok körében (CarltonPerloff [2006]). Ezen feltételek egyidejű fennállása azonban ritka, a valóságban már megjelennek az eltérések a vállalati profitok között, így időszerüvé válik a jövedelmezőségi különbségek okainak kutatása.

Elsőként az ún. IO-iskola (industrial organisations - piaci szerkezetek) nézeteit összefoglaló, Bain és Mason munkásságán alapuló SCP-modell (structure-conductperform - struktúra-magatartás-teljesítmény) szolgáltatott magyarázatot a profitok varianciájára. Az SCP szerint az piacszerkezet (belépési korlátok megléte, a vállalatok mérete, a termékek differenciáltsága és a kereslet árrugalmassága) határozza meg a vállalatok magatartását (ár- és termékpolitika), amely kihat a vállalatok teljesítményére (Bain [1956], [1968]; Porter [1981]). Az SCP-modell támogatói szerint a piacszerkezet milyenségét leíró koncentrációs mérőszámok ${ }^{1}$ magas értékei a cégek összejátszásán keresztül magas árakat és alacsony mennyiségeket előidézve vezetnek magasabb profitokhoz (Edwards et al. [2012]). Ennek igazolására a piac jövedelmezöségét közelítő regressziós egyenleteikbe koncentrációs mutatókat illesztettek és azok szignifikanciájával kívánták alátámasztani elméletüket (Schmalensee [1985]). A modell hiányossága, hogy az említett változók nehezen mérhetők, továbbá a modell csak a piacjövedelmezőségére szolgáltat magyarázatot, az egyes vállalatokéra nem (Carlton-Perloff [2006]).

Porter [1979] elemzésének legfőbb egységévé az ún. stratégiai csoportot megtéve alternatívát kínált az SCP helyett. A stratégiai csoportot a kulcsfontosságú döntési változóik terén hasonló stratégiát követő vállalatok összességeként definiálta. A jövedelmezőséget determináló modelljében a legfőbb összetevők és azok kapcsolata

\footnotetext{
${ }^{1} \mathrm{C} 4, \mathrm{C} 8$, HHI (Herfindahl-Hirschman-index), melyek közül C4 és C8 a 4, illetve 8 piacvezető vállalat részesedését, a HHI-mutató pedig a piaci részesedések négyzetösszegét adja meg (Carlton-Perloff [2006]).
}

Statisztikai Szemle, 96. évfolụam 8-9. szám 818-840. oldal 
a következő: a stratégiai csoportot védő mobilitási korlátok szintje meghatározza a csoport potenciális jövedelmezőségét. Ezt követően az egyes vállalatok tényleges jövedelmezőségét a csoporton belüli verseny erőssége, a vállalatok méretbeli különbségei, a helyettesítők jelenléte, a vállalat azon képessége, hogy stratégiáit megvalósítsa operatív szinten, valamint a stratégiai csoport alkuereje határozzák meg. Így a jövedelmezőség végső soron annak függvénye, hogy a menedzserek képesek-e az iparágon belül egy megfelelően attraktív stratégiai csoportba pozícionálni a vállalatot, ahol a vállalat az említett tényezők legkedvezőbb kombinációjával szembesül.

Porternél tehát az iparágon belüli pozíciónak meghatározó szerepe van, noha az nehezen számszerüsíthető. Így az empirikus kutatások során a szerzők az iparági ${ }^{2}$ tagság meghatározó szerepét kívánták bizonyítani, és igazolták annak jelentős hatását a jövedelmezőségre. Schmalensee [1985] 1975-ös adatokra támaszkodó varianciakomponens-elemzésének eredményei alapján a vállalati hatások nem magyaráznak szignifikáns részt a varianciából, az iparági hatások viszont 20 százalékban magyarázatot szolgáltatnak a profitabilitás indikátoraként használt ROA-mutató változékonyságára.

Ezt az álláspontot vizsgálta felül Barney [1991], aki a vállalatspecifikus tényezőkre, nevezetesen a vállalatok fizikai, humán és szervezeti erőforrásainak heterogenitására és immobilitására helyezte a hangsúlyt a jövedelmezöségbeli eltérések magyarázatakor. Az említett erőforrások értékes, ritka, költségesen másolható és helyettesíthető vonásai azok, melyek lehetővé teszik, hogy a vállalatok tartós versenyelönyt realizálva, átlagon felüli profitokat könyvelhessenek el. Ezt a megközelítést erőforrás-alapúnak (resource-based view) hívja a nemzetközi szakirodalom. A modell empirikus alátámasztása során a szerzők arra törekedtek, hogy a profitok varianciáját minél nagyobb részben vállalatspecifikus tényezőkkel magyarázzák. Rumelt [1991] egyesült államokbeli nagyvállalatok 1974 és 1977 közötti adatait feldolgozva azt találta, hogy a jövedelmezőséget leképező EBIT/Összes eszköz mutató (earnings before interest and taxes - kamat és nyereségadó-ráfordítások levonása elötti eredmény) változékonyságáért 40 százaléknál is nagyobb részben az egyes gazdasági egységek jellemzői tehetők felelőssé, míg az iparági hatások marginálisak e tekintetben.

Miután a különböző modellek létrejöttek, számos szerző tett kísérletet arra, hogy elhatárolja egymástól, illetve számszerüsítse az egyes jövedelmezőségi modellek hozzájárulását a jövedelmezőség változékonyságának megmagyarázásához. A szerzők a jövedelmezőség indikátora varianciájának felbontásával valósították meg mindezeket, melyhez az ANOVA (analysis of variance - varianciaanalízis), a COV (components of variance - varianciakomponensek), illetve a HLM

\footnotetext{
${ }^{2}$ Iparág alatt a továbbiakban olyan vállalatok összességét értjük, melyek valamely gazdaságitevékenységalapú osztályozási rendszer valamely szintjén azonos osztályba kerültek.
} 
(hierarchical linear modeling - hierarchikus lineáris modellezés) eszközrendszerét használták fel. A jövedelmezőség varianciáját jellemzően vállalati, iparági, ország, valamint éves hatások között osztották fel, majd a magyarázott variancia alapján rangsorolták a jövedelmezőségi megközelítéseket. Az ő eredményeiket foglalja össze az 1. táblázat.

Az empirikus kutatási eredmények összefoglalása a mezögazdaság és élelmiszeripar területén - magyarázott variancia (százalék)

\begin{tabular}{|c|c|c|c|c|c|c|c|}
\hline Szerző & Ország/terület & Szektor/Ágazat & Módszer & $\begin{array}{l}\text { Vállalati } \\
\text { hatások }\end{array}$ & $\begin{array}{l}\text { Iparági } \\
\text { hatások }\end{array}$ & $\begin{array}{l}\text { Éves } \\
\text { hatások }\end{array}$ & $\begin{array}{l}\text { Ország- } \\
\text { hatások }\end{array}$ \\
\hline \multirow{2}{*}{$\begin{array}{l}\text { Schiefer- } \\
\text { Hartmann [2009] }\end{array}$} & \multirow{2}{*}{ Európai Unió } & \multirow{2}{*}{ élelmiszeripar } & $\mathrm{COV}$ & $38,1-53,3$ & $0,7-2,3$ & 0,6 & $1,1-2,5$ \\
\hline & & & ANOVA & $49,0-56,0$ & $1,0-3,0$ & $0,4-0,5$ & $1,0-2,0$ \\
\hline \multirow{2}{*}{$\begin{array}{l}\text { Hirsch-Schiefer } \\
\text { [2016] }\end{array}$} & \multirow{2}{*}{ Európai Unió } & \multirow{2}{*}{ élelmiszeripar } & ANOVA & 34,3 & $1,0-4,0$ & 2,2 & 3,5 \\
\hline & & & $\mathrm{COV}$ & 27,0 & 0,6 & 1,4 & 3,6 \\
\hline $\begin{array}{l}\text { Hirsch-Zouaghi- } \\
\text { Garcia [2016] }\end{array}$ & Spanyolország & $\begin{array}{c}\text { mezőgazdaság és } \\
\text { élelmiszeripar }\end{array}$ & HLM & $26,3-48,8$ & $0,8-4,2$ & $0,1-2,5$ & \\
\hline $\begin{array}{l}\text { Chaddad- } \\
\text { Mondelli [2013] }\end{array}$ & $\begin{array}{l}\text { Egyesült } \\
\text { Államok }\end{array}$ & élelmiszeripar & HLM & 36,1 & 7 & 0,5 & \\
\hline
\end{tabular}

Megjegyzés. COV (components of variance): varianciakomponensek; ANOVA (analysis of variance): varianciaanalízis; HLM (hierarchical linear modeling): hierarchikus lineáris modellezés. A táblázatban üres cella jelöli a nem tanulmányozott hatásokat. Az intervallumok több becsült modellre és a magyarázott hányadok terjedelmére utalnak.

A témakörben született empirikus kutatások másik nagy vonulatát képezik azon tanulmányok, melyek jellemzően egyetlen ország egy jól meghatározott iparágáról készültek, és melyek szerzői úgy vélték, hogy az iparág jellegzetességei és a vállalati vonások játszanak szerepet a jövedelmezőség meghatározásában (PervanMlikota [2013]). Ennélfogva a jövedelmezőség választott indikátorát a szerzők vállalatspecifikus és esetenként a piac szerkezetét leíró változókat tartalmazó egyenletekkel próbálták közelíteni. Eredményeiket a teljesség igénye nélkül soroljuk fel a 2. táblázatban, amely az empirikus eredmények jobb áttekinthetőségét szolgálja. 
Az empirikus kutatási eredmények összefoglalása - vállalati és iparági hatások

\begin{tabular}{|c|c|c|c|c|c|c|c|c|c|c|c|c|c|c|}
\hline Függő változó & Szerző(k) & $\stackrel{\bar{\Xi}}{\Sigma}$ & 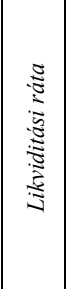 & 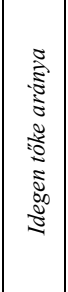 & 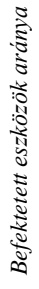 & 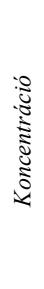 & 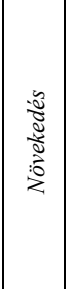 & 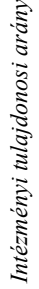 & 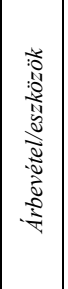 & 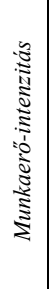 & 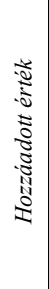 & 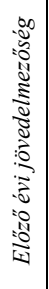 & 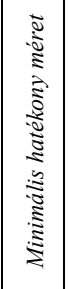 & $\grave{\vdots}$ \\
\hline ROTA, OPM & $\begin{array}{l}\text { Dencic-Mihajlov } \\
{[2014]}\end{array}$ & + & + & n.sz. & & & + & - & + & & & & & \\
\hline ROA & Lazăr [2016] & - & & - & - & & + & & & - & + & & & \\
\hline ROA & Pratheepan [2014] & + & n.sz. & n.sz. & - & & & & & & & & & \\
\hline ROA & $\begin{array}{l}\text { Al-Jafari-Al Samman } \\
{[2015]}\end{array}$ & + & + & - & + & & + & & & & & & & \\
\hline EBITDA-arány & $\begin{array}{l}\text { Pervan-Mlikota } \\
\text { [2013] }\end{array}$ & + & & - & & + & & & n.sz. & & & + & n.sz. & \\
\hline ROA & Fareed et al. [2016] & + & & n.sz. & & & n.sz. & & & & & + & & - \\
\hline $\begin{array}{l}\text { Eszközarányos } \\
\text { üzemi eredmény }\end{array}$ & $\begin{array}{l}\text { Nunes-Serrasqueiro- } \\
\text { Sequeira [2009] }\end{array}$ & + & n.sz. & - & - & & + & & & & & & & \\
\hline ROA, ROE & $\begin{array}{l}\text { Pantea-Gligor-Anis } \\
\text { [2013] }\end{array}$ & + & & & + & & n.sz. & & & & & & & \\
\hline ROA & Yazdanfar [2013] & + & & & & & + & & & & & + & & - \\
\hline ROCE & $\begin{array}{l}\text { Chander-Aggarwal } \\
{[2008]}\end{array}$ & n.sz. & n.sz. & & & & & & & & & + & & + \\
\hline ROA & Doğan [2013] & + & + & - & & & & & & & & & & - \\
\hline
\end{tabular}

Megjegyzés. ROTA (return on total assets): teljes eszközállomány megtérülése; OPM (operating profit margin): üzemi nyereség; EBITDA (earnigs before interest, taxes, depreciation and amortization): kamatok, adók és értékcsökkenés levonása előtti eredmény; ROCE (return on capital employed): befektetett tőke megtérülése. A táblázat tartalmazza a szerzők által használt függö, illetve független változókat, melyek esetenként több modellben is szerepet kaphattak. A sorok és oszlopok metszetében 4 kimenetel lehetséges: „,"” és ,,-" szimbólumok jelölik, ha a szóban forgó változó pozitív, illetve negatív előjellel szerepel a szerzők regressziós egyenleteiben, továbbá a változó együtthatója 5 százalékos szignifikanciaszinten szignifikánsnak minősíthető. Amennyiben a szerzők több modellt is használtak, akkor abban az esetben tüntettük fel szignifikánsként a változó együtthatóját, ha legalább az egyikben szignifikáns volt 5 százalékos szignifikanciaszinten. Az „n.sz.” jelöli a nem szignifikáns együtthatókat. Amennyiben a független változó nem szerepelt a szerző(k) modelljében, a cella üresen maradt. 


\section{Módszertan és modellspecifikáció}

Az irodalmi áttekintés során két irányvonal rajzolódott ki a jövedelmezőségi kutatások terén, melyek közül az egyik elsősorban a jövedelmezőséget befolyásoló legfőbb hatásosztályokra (vállalati, iparági, éves, ország) és azok interakcióira fókuszál (lásd az 1. táblázatot), míg a másik az egyes hatásosztályokat tanulmányozza a vállalatok erőforrás-ellátottságára, illetve az iparág sajátosságaira reflektáló változókon keresztül és paneladatok alapján becslést ad ezen változók hatására. (Lásd a 2. táblázatot.)

Céljaink egyike, hogy az első fejezetben bemutatott eredményekhez a magyar mezőgazdaságban jelenlevő vállalati és időbeli hatások interakcióinak jövedelmezöségre gyakorolt marginális hatásának feltérképezésével járuljunk hozzá. Ugyanakkor tanulmányunkban a hatásosztályok vizsgálatánál mélyebbre kívánunk hatolni, ennek megfelelően vállalati hatásokat megtestesítő változókat alkalmazunk a 2 . táblázat szerzőihez hasonlóan, ugyanis szeretnénk megérteni, hogy a vállalati hatások mely változókon keresztül érvényesülnek, illetve ezek időben előrehaladva miként változnak. Tehát velük ellentétben nem csupán egy adott időszakban érvényesülő átlagos hatásra kívánunk becslést adni, hanem nyomon követjük a hatások időbeli változásait is. Kutatásunk során a 2. táblázatban szereplö változók közül többre is támaszkodunk, hogy az eddigi empirikus kutatások eredményeivel összehasonlíthatóvá váljanak az eredményeink.

Az elemzéshez felhasznált 164 magyar mezögazdasági vállalat 2007 és 2014 közötti adataihoz az Amadeus-adatbázison ${ }^{3}$ keresztül jutottunk hozzá, ami összességében 1312 megfigyelést jelent. Az adatok alapvetően a pénzügyi-számviteli elemzés elterjedt mutatóit foglalják magukban, tehát az éves beszámoló adataiból konstruált mutatókról van szó. A szakirodalom áttekintése során a jövedelmezőség több indikátorával is találkoztunk, melyek közül kutatásunkban a ROA-mutatót ${ }^{4}$ használjuk, hogy rajta keresztül bemutassuk a jövedelmezőségben bekövetkezett változásokat. A ROA számítása során figyelembe vesszük, hogy az egymáshoz viszonyított mutatók egyike folyamat, a másik pedig állomány típusú. Előbbi az időszakra (számviteli évre) vonatkozó adózott eredmény, míg utóbbi az egy időpillanatban értelmezhető eszközállomány. A két típusú mutató „közös nevezőre hozása” érdekében a számítás során a nevezőben az eszközállomány nyitó és záró értékének számtani közepét használjuk vetítési alapként, hogy ezáltal kisimuljanak az eszközállományban év

\footnotetext{
${ }^{3}$ Az Amadeus-adatbázis a Föld számos országában gyüjti a társas vállalkozások éves beszámolóiban fellelhető, illetve az azokból számítható vállalati adatokat. Az adatbázis a vállalatok főtevékenység szerinti osztályozását is elvégzi: a jelen tanulmányban szereplő vállalatok a NACE (Nomenclature statistique des activités économiques dans la Communauté européenne - a gazdasági tevékenységek statisztikai osztályozása az Európai Közösségben) alapján a „mezögazdaság, erdészet és halászat” gazdasági ágba tartoznak.

${ }^{4}$ Adózott eredmény/átlagos eszközállomány.
} 
közben bekövetkezett változások. Ezt a módszert további mutatók számításánál is alkalmazzuk, hogy kisimítsuk vele az üzleti ciklusban meglevő esetleges egyenlötlenségeket. Különösen nagy jelentősége van ennek, például abban az esetben, ha egy vállalat vevői rapszodikusan fizetnek, ami azt eredményezi, hogy a mérlegben szereplő záró érték alul- vagy felülbecsli az átlagos vevőállományt. Az így számított ROA-értékek évenkénti eloszlását egy „box and whisker” ábrán szemléltetjük, amely felhívja a figyelmet a jövedelmezőség 2009-2010-es - a gazdasági világválság hazai kirobbanását követő - visszaesésére. (Lásd az ábrát.)

A ROA-mutató értékeinek évenkénti eloszlása, 2007-2014

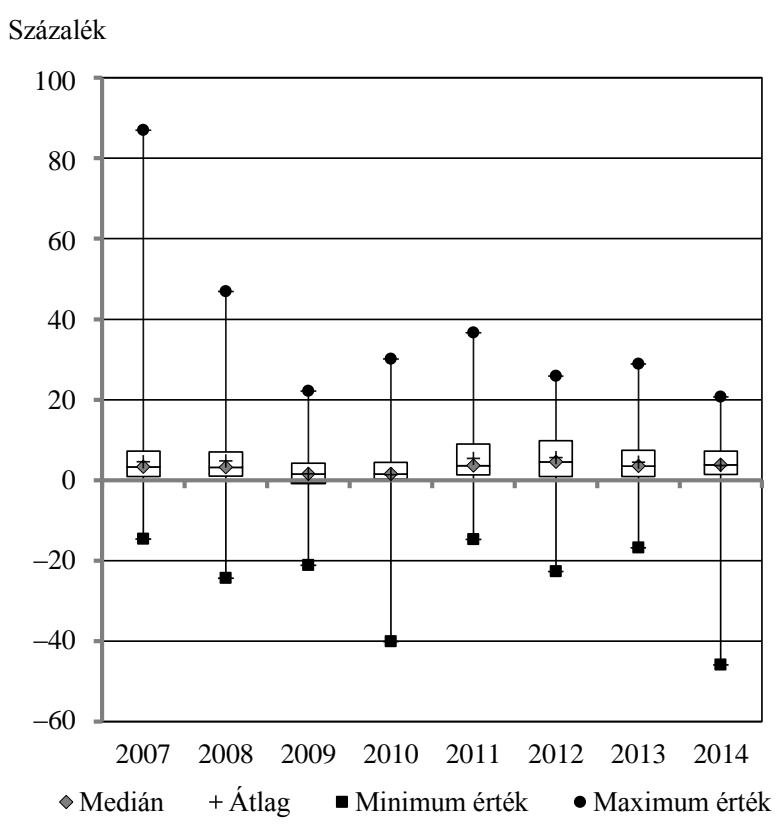

A ROA-értékekben levő változékonyság magyarázhatósága érdekében első lépésként kialakítottunk egy potenciális változókört. Ebben egyrészt az irodalmi áttekintés adott iránymutatást, másrészt az adatállományban rejlő lehetőségeket igyekeztünk kiaknázni. A változók között - melyeket tartalmuk szerint csoportokba soroltunk - akadnak állományi mutatók, de többségben vannak a mérleg-, illetve az eredménykimutatás szerkezetét tükröző változók. Utóbbiakat százalékos formában adtuk meg, így alapegységük százalékpont. Változóink többségét lineáris alakban szerepeltetjük, amennyiben ettől a gyakorlattól valamilyen közgazdasági megfontolás miatt eltérnénk, azt külön jelezzük. 
1. változócsoport. A vállalat forgótőke-menedzsmentjének milyenségét jellemző mutatók:

$X_{1}$ : Vevök forgóeszközökön belüli aránya $=$ vevöklforgóeszközök. Azt tételezzük fel, hogy magas aránya nemkívánatos a jövedelmezőség szempontjából, dacára annak, hogy a vevők könyvelése az árbevétellel szemben történik. Ezt arra alapozzuk, hogy egy relatíve magas vevóállománnyal rendelkező vállalat folyamatosan elszenvedi vevőinek nemfizetési kockázatát. Egy „kiszáradt” likviditású időszakban különösen jelentős annak kockázata, hogy az egyéb ráforditásokkal szemben a követelésekre értékvesztést kell elszámolni. Az elszámolt értékvesztés összege ráadásul a társasági adóról és osztalékadóról szóló törvény alapján adóalapot növelő tétel, vagyis megnöveli a fizetendő adó értékét, és ezáltal rontja a jövedelmezőséget. Így véleményünk szerint a jövedelmezőség javítása érdekében a vevőállomány csökkentése kívánatos. Továbbá azt feltételezzük, hogy a vevőkövetelések arányának növekedése az aránymutató magasabb szintjein markánsabb hatást fejt ki a jövedelmezőségre, tehát a változó kvadratikus alakban szerepeltetendő.

$X_{2}$ : Szállitók idegen tökén belüli aránya = szállitók/idegen tőke. A változó értéke arról árulkodik, hogy milyen arányban tud a vállalat kamatmentes hitelt bevonni a finanszírozásba. Úgy véljük, a változó pozitív irányú kapcsolatban áll a jövedelmezőséggel, ugyanis növekedése mögött a forrásszerkezet átalakítása áll, melynek során a kamatozó (és ezáltal az adózott eredményt rontó) források szerepét a szállítók veszik át a finanszírozásban.

$X_{3}$ : Likviditási ráta $=$ forgóeszközök/rövid lejáratú kötelezettségek. A ráta emelkedését a jövedelmezőség szempontjából kedvező folyamatnak tartjuk, ugyanakkor túlontúl magas értéke elfekvő készletekre (fontos tényező, hogy a mezőgazdaság termékeinek eltarthatósága korlátozott, szemben más ágazatok termékeivel), nem forgatott pénzeszközállományra, behajthatatlan követelésekre utalhat. Éppen ezért feltételezésünk szerint a ráta növekedése egyre kisebb növelö hatást fejt ki a jövedelmezőségre, vagyis egy logaritmusfüggvény írja le legpontosabban a kapcsolat természetét.

2. változócsoport. A vállalat költségszerkezetét leíró változó:

$X_{4}: S z J R$ (személyi jellegü ráfordítások) költségszerkezetbeli súlya (SzJRarány $)=S z J R /(S z J R+$ anyagjellegü ráforditások + értékcsökkenési leirás $)$. A változó a vállalat költségszerkezetét tükrözve mutatja, hogy mennyire munkaigényes a tevékenység. A mintában alapvetően a munkavállalókhoz kapcsolódó ráfordítások alacsony arányával szembesültünk (23,23 százalék a mutató átlagos értéke). A változó modellbe illesztésével azt teszteljük, hogy magasabb hozzáadott értéket képviselnek-e azon vállalatok, melyek tevékenysége relatíve munkaigényesebb, tehát prognózisunk a változó együtthatójának előjelére pozitív.

3. változócsoport. Az árbevétel alakulását leíró változók: 
$X_{5}$ : Árbevétel/eszközök. A változó az eszközállomány egysége által generált árbevétel megadásán keresztül, annak hatékonyságáról informál, és várakozásaink szerint pozitív kapcsolatban áll a ROA-val.

$X_{6}$ : Méret: az árbevétel természetes alapú logaritmusa. A változó együtthatójának 1/100 része megmutatja, miként reagál a ROA-mutató az árbevétel 1 százalékos változására. Pozitív előjele méretgazdaságosságra utal, ugyanis ekkor a vállalat a költségek nagyobb arányú növekedése nélkül tudja emelni az árbevételét.

4. változócsoport. A vállalati eszköz- és forrásszerkezetet jellemző változók:

$X_{7}$ : Idegen töke aránya $=$ idegen töke/összes forrás. A változó magas értéke egyrészt arra világít rá, hogy a vállalat az elmúlt években nem termelt megfelelő menynyiségü forrást eszközeinek finanszírozására (vagyis nem volt eléggé jövedelmezö), másrészt a fizetett kamatokon keresztül rontja a tárgyévi adózott eredményt és a hitelképességet is. Így egy negatív irányú kvadratikus kapcsolatot tételezünk fel.

$X_{8}$ : Befektetett eszközök aránya = befektetett eszközök/összes eszköz. A változó hatását elsősorban az értékcsökkenési leíráson keresztül fejti ki, e hatás várakozásaink szerint negatív a jövedelmezöség szempontjából.

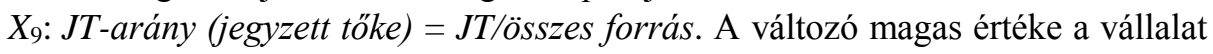
kevésbé jövedelmező múltjáról informál, így várakozásaink szerint a jövedelmezöséget kedvezötlen irányba mozgatja.

5. változócsoport.

$X_{10}:$ Beruház $=\left\{\begin{array}{c}1, \text { ha Nettó beruházás }>0 \\ 0, \text { egyébként }\end{array}\right.$.

A változónak előzetesen jövedelmezőséget javító hatást tulajdonítunk.

$X_{11}$ : Egyéb bevételek aránya $=($ egyéb bevételek + aktiv saját teljesitmények értéke)/összes eszköz. ${ }^{5}$ A változónak fontos szerepet tulajdonítunk, mivel rávilágít a megtermelt, de nem értékesített javak, a müködési támogatások, valamint az egyéb - alaptevékenységhez nem kapcsolódó - tételek szerepére a jövedelmezőség meghatározásában. Várakozásaink szerint a lineáris változóhoz pozitív előjelủ együttható társul a becsléseknél.

6. változócsoport. Az éves hatások teszteléséhez szükséges dummy változókat $\left(D_{t}\right)$ tartalmazza, melyek a ROA modellezésének második szakaszában kapnak kitüntetett szerepet, ezeket a következőképpen definiáljuk:

$D_{t}=\left\{\begin{array}{c}1, \text { a } 2000 \text { utáni } t \text {-edik évben } \\ 0, \text { egyébként }\end{array}\right.$.

Az így létrejövő változókör egyes elemei olyan gazdasági folyamatokat számszerüsítenek, melyek hatása nemcsak a tárgyév, hanem a soron következő pénzügyi év

\footnotetext{
${ }^{5} \mathrm{Az}$ egyéb bevételek és az aktivált saját teljesitmények értéke szokatlan kombinációját az Amadeusadatbázis szerkezete indokolja, melyből csak az összegük nyerhető ki, különálló értékük nem.
}

Statisztikai Szemle, 96. évfolụam 8-9. szám 818-840. oldal 
jövedelmezöségében is érvényesülhet. Ebből kifolyólag több változó esetén is (kiváltképp olyan változókén, melyek befolyásolhatják egy hitelkérelem elbírálását) szükségszerünek tartjuk a változó késleltetett értékének szerepeltetését. Az általunk alkalmazott késleltetési struktúrát a 3. táblázatban foglaltuk össze.

3. táblázat

A potenciális magyarázó változók késleltetési struktúrája

\begin{tabular}{l|c|c}
\hline \multicolumn{1}{c|}{ Változó } & Föhatás & Késleltetett hatás \\
\hline Beruház & & $\mathrm{x}$ \\
\hline Méret & $\mathrm{x}$ & $\mathrm{x}$ \\
\hline Vevöarány & $\mathrm{x}$ & $\mathrm{x}$ \\
\hline Szállítók aránya & $\mathrm{x}$ & $\mathrm{x}$ \\
\hline Likviditási ráta & $\mathrm{x}$ & $\mathrm{x}$ \\
\hline SzJR-arány & $\mathrm{x}$ & $\mathrm{x}$ \\
\hline Árbevétel/eszközök & $\mathrm{x}$ & $\mathrm{x}$ \\
\hline Idegen töke aránya & $\mathrm{x}$ & $\mathrm{x}$ \\
\hline Befektetett eszközök aránya & $\mathrm{x}$ & \\
\hline JT-arány & & $\mathrm{x}$ \\
\hline Egyéb bevételek aránya & & \\
\hline
\end{tabular}

Megjegyzés. SzJR: személyi jellegű ráfordítások; JT: jegyzett tőke. x a hatás alkalmazását jelöli.

A bemutatott változókkal történő modellezést két fázisra osztjuk, hogy megállapíthassuk, mely vállalati hatások játszanak szerepet a vállalati jövedelmezőség változékonyságban, valamint képet kapjunk ezek időbeli alakulásáról.

Az első szakaszban azt vizsgáljuk, hogy a jövedelmezőséget potenciálisan magyarázó változók közül melyek állnak tényleges kapcsolatban annak indikátorával. Ehhez egy új szelekciós megközelítést választunk, melynek során két szürőként funkcionáló változót szerepeltetünk az /1/ egyenlet jobb oldalán. Így a következő panelmodellt becsüljük az LSDV-módszerrel (least squares dummy variables estimator - fix hatású panelbecslés dummy változó(k) bevonásával): ${ }^{6}$

$$
\begin{aligned}
R O A_{i t} & =\alpha_{i}+\sum_{k} \beta_{k} X_{k i t}+\sum_{k} \beta_{k} X_{k i(t-1)}+\sum_{k} \beta_{k} X_{k i t}^{2}+\sum_{k} \beta_{k} X_{k i(t-1)}^{2} \\
& +\sum_{k} \beta_{k} \log \left(X_{k i t}\right)+\sum_{k} \beta_{k} \log \left(X_{k i(t-1)}\right)+\gamma R O A_{i(t-1)}+\delta \log \left(R O A_{i t}\right)+\varepsilon_{i t}
\end{aligned}
$$

${ }^{6}$ A fix hatású modell alkalmazását többek között az is indokolja, hogy használatával kontrollálni tudjuk a nem megfigyelhető és nem is mérhető időfüggetlen, vállalatspecifikus hatásokat (például a müvelt földterület minősége). 
ahol a $\beta_{k}-\mathrm{k}, \gamma$ és $\delta$ az egyes független változók ROA-ra gyakorolt parciális hatását számszerüsítik a többi változó értékének változatlansága mellett, $\alpha$ a tengelymetszeti paraméter, $\varepsilon$ pedig a megfigyelt és a becsült ROA-értékek különbsége. A $k$ futóindex a $k$-adik független változóra, az $i$ az $i$-edik vállalatra, míg $t$ a $t$-edik évre utal. Az egyenletek paramétereit a Gretl for Windows ökonometriai program használatával becsüljük. A modell független változói között szerepeltetjük a ROA jövedelmezöségi mutató időben $(t-1)$ késleltetett értékét és egyidejü logaritmusát is. Ez annak érdekében történik, hogy e kétféle trend egyidejű szürése után, a többi regressziós paraméter lineárisan szürt, „,de-trended”, specifikációs torzítástól mentes marginális hatást mérjen. A logaritmálást az időbeni exponencialitás „linearizálására”, az elsőrendủ autoregresszív tag bevonását pedig a linearitás szürésére alkalmazzuk, a stacionaritás érdekében. Új megközelítés, hogy itt egy parametrikus és egy nemparametrikus trendszürés kombinálódik. A szürőket a később becsült modellből értelemszerüen elhagyjuk.

A modellezés második szakaszában - az első szakaszban kiválogatott változók használatával - az ún. strukturális törést valósítjuk meg, melynek során azt tételezzük fel, hogy a változók közötti kapcsolat évről évre változó természetü. Ezt arra alapozzuk, hogy egy meglehetősen hosszú, gazdaságtörténetileg eseménydús időszakot vizsgálunk, amely szükségszerüvé teszi a vállalati hatások időbeli állandóságára tett megszorítás feloldását. Elegendő a gazdasági világválságra gondolnunk, melynek következményeként 2008-ban drasztikusan megemelkedett a jegybanki alapkamat, ${ }^{7}$ amely aztán a válságkezelés során alkalmazott monetáris politika következtében csökkenő pályára állt, vélhetően a fizetett kamatokon keresztül befolyásolva az idegen töke aránya változó jövedelmezőségre kifejtett hatását. A válság következtében, likviditáshiányos helyzetben, nehézzé vált a vevőkövetelések behajtása, és felértékelödött a kamatmentes szállítói finanszírozás szerepe, amikor is a bankhitelek állománya 2008 és 2009 között 8,7 százalékkal esett vissza a magyar mezőgazdaság társas vállalkozásainál (Kemény [2010]).

A mezőgazdasági termékek keresletében és kínálatában bekövetkezett változások, valamint az árfolyamok változása az árbevételt tartalmazó változók hatását évröl évre módosíthatták. Ezen kívül a válság sújtotta időszakban felértékelődik a támogatások szerepe is, melyet - ugyan nem tiszta formában - az egyéb bevételek aránya tartalmaz, továbbá a társaságiadó-fizetés szabályaiban végbement változások (2010-től 50-ről 500 millió forintra emelkedett az adóalap 10 százalékos kulccsal adózó része) szintén módosíthatták bizonyos változók hatásait. ${ }^{8}$ Mindezeket tesztelendő a következő - szintén fix hatású - modellt becsüljük:

\footnotetext{
${ }^{7}$ https://www.mnb.hu/Jegybanki_alapkamat_alakulasa?datefrom=2007.04.29.\&datetill=2010.04.29.\&order=0

${ }^{8} \mathrm{http}: / /$ nav.gov.hu/nav/archiv/adoinfo/tarsasagi/tao_valtozasok.html
} 


$$
\begin{aligned}
R O A_{i t} & =\alpha_{i}+\sum_{k} \sum_{t=08}^{14} \beta_{k t}\left(D_{t} X_{k i t}\right)+\sum_{k} \sum_{t=08}^{14} \beta_{k(t-1)}\left(D_{t} X_{k i(t-1)}\right)+ \\
& +\sum_{k} \sum_{t=08}^{14} \beta_{k t}\left(D_{t} X_{k i t}^{2}\right)+\sum_{k} \sum_{t=08}^{14} \beta_{k(t-1)}\left(D_{t} X_{k i(t-1)}^{2}\right)+ \\
& +\sum_{k} \sum_{t=08}^{14} \beta_{k t}\left(D_{t} \log \left(X_{k i t}\right)\right)+\sum_{k} \sum_{t=08}^{14} \beta_{k(t-1)}\left(D_{t} \log \left(X_{k i(t-1)}\right)\right)+\varepsilon_{i t}
\end{aligned}
$$

ahol $\beta_{k t}$ méri a $k$-adik változó $t$-edik évbeli jövedelmezőségre kifejtett hatását. A modell /2/ specifikációja mellett szükségszerúen elveszítjük a legkorábbi év megfigyeléseit, ezért a föhatások csak 2008 és 2014, míg a késleltetett hatások csak 2007 és 2013 között értelmezhetők, a becsléseket pedig 1148 megfigyelés alapján végezzük el.

\section{A regresszióanalízis eredményei}

Az /1/ egyenletben bemutatott segédregresszió becslése után alkalmaztuk azt az új - közgazdasági hipotéziseinken (lásd a 3. táblázatot) alapuló - megközelítést, melynek keretein belül az induló (full) modellt nem automatikus szelektáló algoritmus által, hanem szakmai úton szükítettük olyan módon, hogy minden lépésben elhagytuk azt a változót, melyhez a legmagasabb $p$-érték tartozott - feltéve, hogy az 25 százalék feletti volt, és elhagyásával nem esett ki olyan változó, melyet a vonatkozó irodalom a jövedelmezőség releváns meghatározójaként tart számon -, majd újrabecsültük a modellt. ${ }^{9}$ Amennyiben a legmagasabb $p$-értékü változót nem hagytuk el, a $p$-érték szerint sorba rendezett változók közül a soron következőre érvényesítettük az előbbiekben leírt metódust, és így tovább. A szakirodalom által relevánsnak tartott változó megtartása alól egyedül a méret változó képez kivételt, melynek elhagyásával amellett döntöttünk, hogy az árbevétel hatását az árbevétel/eszközök változón keresztül tanulmányozzuk. Az ötödik lépés után már nem szembesültünk elhagyandó változóval, így az öt lépés után előálló (szükített) modell változóit használtuk fel a modellezés következő lépésében:

\footnotetext{
${ }^{9}$ Felhívjuk az Olvasó figyelmét arra, hogy eljárásunk során statisztikailag nem szignifikáns együtthatójú változókat is benntartottunk a modellben, és azokat további tanulmányozás alá vontuk. Ezzel az eljárással kívántunk összhangot teremteni a statisztikai hipotézisvizsgálat, illetve a szakmai alapokon nyugvó modellépítés között.
} 
A változószelekcióra szolgáló segédregresszió modelltáblája

\begin{tabular}{|c|c|c|c|c|}
\hline \multirow{2}{*}{ Változó } & \multicolumn{2}{|c|}{$\begin{array}{c}\text { Full modell } \\
\text { LSDV } R^{2}=0,8278\end{array}$} & \multicolumn{2}{|c|}{$\begin{array}{c}\text { Szükített modell } \\
\text { LSDV } R^{2}=0,8276\end{array}$} \\
\hline & Együttható & $p$-érték & Együttható & $p$-érték \\
\hline Konstans & 1,4164 & 0,8010 & 2,2576 & 0,3634 \\
\hline Beruház_1 & $-0,4216$ & 0,1747 & $-0,3872$ & 0,1520 \\
\hline Méret & 0,1129 & 0,8724 & & \\
\hline Befektetett eszközök aránya & $-0,0481 *$ & 0,0663 & $-0,0486^{*}$ & 0,0542 \\
\hline Befektetett eszközök aránya_l & 0,0321 & 0,1735 & 0,0342 & 0,1248 \\
\hline Árbevétel/eszközök & $0,0202 *$ & 0,0533 & $0,0215^{* * *}$ & 0,0002 \\
\hline Árbevétel/eszközök_1 & 0,0067 & 0,3121 & 0,0065 & 0,1461 \\
\hline Szállitók aránya & $-0,0519 * * *$ & $<0,0001$ & $-0,0514 * * *$ & $<0,0001$ \\
\hline SzJR-arány & $-0,0619$ & 0,1058 & $-0,0586^{*}$ & 0,0558 \\
\hline SzJR-arány_1 & 0,0101 & 0,7027 & & \\
\hline JT-arány_1 & 0,0043 & 0,8456 & & \\
\hline Egyéb bevételek aránya & $0,0754 * * *$ & 0,0001 & $0,0752 * * *$ & $<0,0001$ \\
\hline $\log ($ Likviditási ráta $)$ & $0,7234 * *$ & 0,0169 & $0,7338 * * *$ & 0,0032 \\
\hline log(Likviditási ráta)_1 & $-0,8479 * * *$ & 0,0012 & $-0,8248 * * *$ & 0,0013 \\
\hline sq_Vevök aránya & 0,0001 & 0,6861 & & \\
\hline sq_Vevök aránya_1 & $-1,2005 \mathrm{e}-06$ & 0,9956 & & \\
\hline sq_Idegen tőke aránya & $-0,0008 * *$ & 0,0491 & $-0,0007 * * *$ & 0,0051 \\
\hline sq_Idegen töke aránya_1 & $0,0008 * *$ & 0,0377 & $0,0008 * * *$ & 0,0017 \\
\hline $\log (R O A)$ & $3,0962 * * *$ & $<0,0001$ & $3,0917 * * *$ & $<0,0001$ \\
\hline$R O A \_1$ & $-0,0073$ & 0,7938 & $-0,0081$ & 0,6676 \\
\hline
\end{tabular}

Megjegyzés. LSDV (least squares dummy variables estimator): fix hatású panelbecslés dummy változó(k) bevonásával; SzJR: személyi jellegü ráfordítások; JT: jegyzett tőke; ROA (return on assets): eszközarányos nyereség. A veszteséges vállalatok mintabeli jelenléte, valamint a ROA logaritmikus transzformációja miatt megfigyeléseket veszítettünk, így a modellt 975 megfigyelés alapján becsültük. A változók elnevezésében szereplö "_1" a késleltetett hatásra utal. *** $p<0,01 ; * * p<0,05 ; * p<0,1$.

Forrás: Saját számítás a Gretl for Windows program segítségével.

A segédregresszió alapján a jövedelmezőség szempontjából legfontosabb változók között szerepel kettő a forgótőke-menedzsment milyenségét leíró változók csoportjából, egy a költségszerkezetet leíró változó, ismét egy az árbevétel alakulását tükröző változók közül, egy-egy az eszköz- és forrásszerkezetre reflektáló változók közül, valamint a beruház és az egyéb bevételek aránya. 
Az /1/ egyenlet változóinak szúkítésével nyert változókört a /2/ egyenletben használtuk fel, tekintve azoknak az éves dummy változókkal képzett interakcióit. ${ }^{10}$ Mindezt lásd a Függelék táblázatában.

A jövedelmezőség indikátorának magyarázata érdekében alkalmazott fix hatású modell a jövedelmezőség varianciájának 69,66 százalékát magyarázza, továbbá a Hausman-teszt alapján ( $p$-érték $=6,9512 \mathrm{e}-007$ ) egyértelmüen preferált a konkurens véletlen hatású modellel szemben. A hipotézisvizsgálat során arra is fényt derült, hogy elutasítandó az a nullhipotézis ( $p$-érték $=2,02551 \mathrm{e}-030$ ), mely szerint a keresztmetszeti egységek közös konstanssal rendelkeznek.

Modellünk tanúsága szerint a pozitív nettó beruházás nem csapódik le a jövő évi jövedelmezőségben, ugyanis a késleltetett beruház változó együtthatója egyik évben sem szignifikáns. Ez arra utal, hogy a tartóseszköz-állomány bővítése egy éven belül még nem térül meg a jövedelmezőségben.

A befektetett eszközök aránya jellemzően negatív együtthatóval szerepel, amely a beruház változóval egyetemben a tartóseszköz-állomány bővítése ellen és a forgóeszköz-állomány bővítése mellett szól.

Az eszközállomány hatékonyságát jelzö árbevétel/eszközök változó pozitív együtthatójú. A mutató 1 százalékpontos növekedését a vizsgált években a ROA 0,036 és 0,128 százalékpont közötti azonos irányú elmozdulása követte. A változó együtthatójában nem figyelhető meg trend, míg késleltetettjének jellemzően nincs hatása a jövedelmezőségre, tehát az előző évi hatékonyan müködtetett eszközállomány nem garantálja a tárgyévi magas jövedelmezőséget, amely rávilágít a költségek változékonyságára.

A szállítók aránya kifejezetten erős negatív hatást fejt ki a jövedelmezőségre, amely ellentétes a várakozásainkkal. A változó abszolút értelemben vett hatásnagysága az időszak közepén visszaesett, majd annak végére ismét megerősödött.

Ugyan az SzJR-arány változó csak két évben kapott szignifikáns pozitív együtthatót, a változónak nagy szakmai fontosságot tulajdonítunk, ugyanis pozitív előjelü együtthatói alapján beigazolódott az a feltételezésünk, hogy azon vállalatok, amelyek költségszerkezete az $S z J R$ dominanciájáról árulkodik, magasabb jövedelmezöségi szintet képviselnek.

Az egyéb bevételek aránya rendre pozitív hatást fejtett ki a jövedelmezöségre, amely 2010 után vált igazán erőteljessé, igazolván az egyéb tételek - köztük a támogatások - kitüntetett szerepét a mezőgazdasági vállalatok jövedelmezőségét illetően.

A likviditási ráta logaritmusa jellemzően pozitív hatást fejt ki a jövedelmezőségre, amely 2009-ben és 2010-ben csökkent zéróközeli tartományba, magyarázatot nyújtva ezen évek gyenge jövedelmezőségére. A többi évben a ráta 1 százalékos növekedése 1,29/100 és 3,85/100 közötti százalékpontos javulást idézett elő a jövedelmezöségben. A likviditási ráta logaritmusának késleltetettje ugyanakkor rendre

\footnotetext{
${ }^{10} \mathrm{Az}$ interakciók eredményeként létrejövő változók elnevezése rendre tartalmazza, hogy mely évet leíró dummy változó a szóban forgó interakció egyik tényezője. Így például árbevétel/eszközök $k_{14}:=($ árbevétel/eszközök $) * D_{14}$
} 
negatív előjelü együtthatót kapott, melynek értelmében a magas likviditás javítja a tárgyévi jövedelmezőséget, viszont rontja a jövő évit. Ennek lehetséges magyarázata, hogy a magas likviditás beruházások elmaradására utalhat.

Az idegen tőke arányának négyzete várakozásainkkal összhangban negatív hatást fejt ki, viszont késleltetettje már pozitív hatású a jövedelmezőségre. E mögött az állhat, hogy a hitelfelvétel egy beruházáshoz hasonlóan hosszú távon fejti ki kedvező hatását. Mindez nehezen egyeztethető össze a szállitók idegen tőkén belüli arányának szintén negatív hatásával. Ezek szerint az idegen töke aránya nem a fizetett kamatokon keresztül fejti hatását, mert akkor azt a szállitók aránya enyhítené. Figyelemre méltó továbbá, hogy a változó 2010 után gyengébb hatást fejt ki, ami összhangban áll a csökkenő kamatkörnyezettel.

\section{Konklúziók}

Tanulmányunkban a magyar mezögazdasági vállalatok sokaságából vett 1312 elemü mintán keresztül igyekeztünk feltárni a vállalati jövedelmezőséget meghatározó tényezőket. Az empirikus tanulmányok által számba vett hatások közül az iparági hatások kvantifikálásához nem rendelkeztünk elegendő információval, az országhatások tanulmányozása pedig nem volt releváns a kizárólag hazai vállalatokat tartalmazó mintából fakadóan. Így figyelmünket azon (a vállalatok erőforrásellátottságát és egyedi jellemzőit számszerüsítő) változók felé fordítottuk, melyeken keresztül a vállalati hatások érvényesülhetnek. Bizonyos változók esetében késleltetett hatásokat is vizsgáltunk. A változókörünk szükítésekor egy speciális panelmodell használatát szakmai megfontolásokkal ötvöztük. Mivel gazdaságtörténeti szempontból eseménydús időszakot vizsgáltunk, modellünket úgy specifikáltuk, hogy nyomon követhessük az egyes változók parciális hatásának időbeli változásait.

A magyar mezőgazdasági vállalatok mintájából nyert eredményeink összhangban vannak a szakirodalom eredményeivel abban a tekintetben, hogy a vállalati és éves hatások interakcióival a jövedelmezőség változékonysága nagy részben (közel 70 százalékban) magyarázhatónak bizonyult. Az egyes változók hatásait illetően eredményeink a következőképpen illeszkednek az eddigi empirikus kutatások létrehozta keretrendszerbe: a vállalatméretet leíró változó nem ment át az általunk alkalmazott segédregresszió próbáján, tehát nem áll szignifikáns kapcsolatban a ROA-val. Ez az eredmény összhangban van Pervan-Mlikota [2013], illetve Chander-Aggarwal [2008] eredményeivel, számos szerző eredményeitől viszont eltér. (Lásd a 2. táblázatot.) A likviditási ráta esetében a kapcsolatot leíró függvényformát illetően a logaritmikusra esett a választásunk, a hatás iránya azonban így is összhangban van Dencic-Mihajlov [2014], Al-Jafari-Al Samman [2015], illetve Doğan [2013] kutatási eredményeivel. A 
finanszírozás szerkezetét leíró idegen tőke arányának négyzete negatív együtthatót kapott a becslések során, tehát a tárgyévi eladósodottság kedvezőtlenül érinti a tárgyévi jövedelmezőséget (Lazăr [2016], Al-Jafari-Al Samman [2015], Pervan-Mlikota [2013], illetve Nunes-Serrasqueiro-Sequeira [2009] eredményeihez hasonlóan), a jövő évit azonban már kedvezően, ami a hitelfelvétel hosszú távú jövedelmezőségjavító szerepére világít rá. A befektetett eszközök arányát illetően az áttekintett eredmények köre meglehetősen változatos. Az általunk becsült negatív hatással Lazăr [2016], Pratheepan [2014], illetve Nunes-Serrasqueiro-Sequeira [2009] eredményeihez csatlakozunk. Az árbevétel/eszközök változó Dencic-Mihajlov [2014] eredményeihez hasonlóan évröl évre pozitív parciális hatást fejtett ki a jövedelmezőségre. ${ }^{11}$ A többi általunk használt változó esetében az áttekintett szakirodalom nem nyújtott összevetési alapot, így csak a saját elözetes várakozásainkkal tudjuk összevetni a hatások nagyságát és irányát. Ez az összevetés meglepő eredményt hozott a szállitók aránya esetében, amely várakozásainkkal ellentétben nem javítja, hanem rontja a tárgyévi jövedelmezöséget. Az SzJR-arány mutató esetén az eredmények alátámasztották az előzetes feltevéseinket, ugyanis a változó együtthatója minden évben pozitív elöjelü volt. A vevök arányának jövedelmezőséget rontó, illetve a beruházás jövedelmezőséget javító hatására nem sikerült empirikus bizonyítékot találnunk. Végül az egyéb bevételek arányának becsült együtthatóját tekintve beigazolódott feltevésünk, miszerint a változó pozitív hatást fejt ki a jövedelmezöségre.

Az eddig lefolytatott empirikus kutatásokhoz képest többletet kívántunk nyújtani azáltal, hogy késleltetett magyarázó változókat is alkalmaztunk. Az ezzel kapcsolatos eredményeink közül az a legfigyelemreméltóbb, hogy a tárgyévi magas likviditás rontja a jövő évi jövedelmezőséget, amely mögött elmaradt beruházások, szükségtelenül magas pénzeszközállomány, behajthatatlan követelések és elfekvő készletek állhatnak. Ezzel szemben az idegen töke arányának tárgyévi magas értéke javítja (ráadásul a késleltetés nélküli változónál abszolút értelemben nagyobb mértékben) a jövő évi jövedelmezőséget, rávilágítva arra, hogy a vállalkozások jövőbeli profitabilitása szempontjából kulcsfontosságú a külső források bevonása a finanszírozásba.

Tanulmányunkban szakítottunk azzal a gyakorlattal, hogy csupán az egyes változók egy időszakon keresztül érvényesülő átlagos hatására adjunk becslést. Ehelyett megvalósítottuk az évek szerint történő strukturális törést, mely lehetőséget adott az egyes változók hatása időbeli alakulásának tanulmányozására. Ez alapján a 2009-es és 2010-es évek gyenge jövedelmezőségét az indokolja, hogy a befektetett eszközök aránya ekkor fejtette ki a legerősebb negatív hatását, az egyéb bevételek aránya ebben az időszakban még kevésbé markáns hatású volt, mint a későbbi években, a likviditási ráta hatása pedig e két évben alakult a legkedvezőtlenebbül a jövedelmezőség szempontjából.

${ }^{11}$ Jelen tanulmány megerősíti azt a tényt, hogy a jövedelmezőség meghatározói, valamint azok hatásának iránya és nagysága országonként, iparáganként eltérő lehet. Ennek számos oka van, melyek végiggondolását az Olvasóra bízzuk. 
A pénzügyi regresszorváltozók szelektálása során - az együtthatók specifikációs torzítottságának csökkentése érdekében - az induló modellben szerepeltettük a jövedelmezőség logaritmusát és az időben egy évvel késleltetett értékét is. A végső becsült modellben már nem szerepelnek e változók.

A magyar mezőgazdaság 164 vállalatának 2007 és 2014 közötti jövedelmezőségét tanulmányozva összességében azt állíthatjuk, hogy a jövedelmezöség befolyásolható a vállalatok eszközszerkezeti és finanszírozási döntésein keresztül: javíthatja a profitabilitást a forgóeszközök irányába való eltolódás az eszközoldalon, illetve egy finanszírozási struktúraváltás, amely a hosszú távú jövedelmezőség érdekében megnöveli az idegen tőke arányát. Bebizonyosodott, hogy a munkavállalókra relatíve többet költő vállalatok jövedelmezőbbek, hogy nagyon is fontos az ágazatban az egyéb tételek hatása, illetve, hogy a kamatmentes hitelt nyújtó szállitók arányának növelése az idegen tőkén belül kedvezőtlenül hat a jövedelmezőségre. Ezek közül hatásnagyság tekintetében az egyéb bevételek aránya és a szállitók aránya a legmarkánsabb tényezők.

További kutatásunk tárgyát képezi a hazai mezőgazdaság helyzetének értékelése európai viszonylatban. Ezen kívül evidenciában tartjuk, hogy a jövedelmezőségi kutatások másik nagy területe a profitok tartós fennmaradására (Hirsch-Gschwandtner [2013], Hirsch-Hartmann [2014], Gschwandtner [2012]) fókuszál, és arra keresi a választ, hogy tartósan fenntarthatók-e az átlagtól eltérő profitok, vagy végbemegy a kompetitív szinthez való igazodás egy bizonyos igazodási sebességgel. Ez szintén perspektivikus kutatási terület, melynek eredményeihez a jövőben magunk is hozzá szeretnénk járulni.

\section{Függelék}

A strukturális törés modellje, amelynek becslése 164 magyar mezögazdasági vállalat 2007 és 2013 közötti adataira támaszkodva készült

\begin{tabular}{l|c|c}
\hline \multirow{2}{*}{ Magyarázó változó } & \multicolumn{2}{c}{ LSDV $R^{2}=0,6966$} \\
\cline { 2 - 3 } & Együttható & $p$-érték \\
\hline Konstans & $-1,5720$ & 0,7672 \\
\hline Beruház13_1 & $-0,2289$ & 0,8864 \\
\hline Beruház12_1 & 0,5835 & 0,8597 \\
\hline Beruház11_1 & 0,8494 & 0,1843 \\
\hline Beruház 10_1 & $-1,4287$ & 0,1033 \\
\hline Beruház 09_1 & $-0,2074$ & 0,8901 \\
\hline Beruház 08_1 & 1,0948 & 0,4212 \\
\hline Beruház 07_1 & $-0,8552$ & 0,4218 \\
\hline
\end{tabular}

(A táblázat folytatása a következö oldalon.) 
(Folytatás.)

\begin{tabular}{|c|c|c|}
\hline \multirow{2}{*}{ Magyarázó változó } & \multicolumn{2}{|c|}{ LSDV $R^{2}=0,6966$} \\
\hline & Együttható & $p$-érték \\
\hline Befektetett eszközök arányal4 & $-0,0033$ & 0,9727 \\
\hline Befektetett eszközök arányal3 & $-0,1835$ & 0,1899 \\
\hline Befektetett eszközök aránya13_l & $-0,0252$ & 0,7979 \\
\hline Befektetett eszközök arányal2 & $-0,1779^{*}$ & 0,0693 \\
\hline Befektetett eszközök. aránya12_1 & 0,1183 & 0,3802 \\
\hline Befektetett eszközök arányal1 & 0,0448 & 0,5686 \\
\hline Befektetett eszközök arányal1_1 & 0,0929 & 0,3130 \\
\hline Befektetett eszközök. aránya10 & $-0,2540^{* *}$ & 0,0359 \\
\hline Befektetett eszközök aránya10_1 & $-0,1008$ & 0,2412 \\
\hline Befektetett eszközök aránya09 & $-0,3226^{* * *}$ & 0,0038 \\
\hline Befektetett eszközök aránya09_1 & 0,1740 & 0,1379 \\
\hline Befektetett eszközök aránya08 & $-0,2270^{* *}$ & 0,0372 \\
\hline Befektetett eszközök aránya08_1 & $0,2868 * * *$ & 0,0058 \\
\hline Befektetett eszközök aránya07_1 & 0,1421 & 0,1507 \\
\hline Árbevétel/eszközök14 & $0,0935 * * *$ & $<0,0001$ \\
\hline Árbevétel/eszközök13 & $0,0625^{* * *}$ & $<0,0001$ \\
\hline Árbevétel/eszközök13_l & $-0,0002$ & 0,9915 \\
\hline Árbevétel/eszközök12 & $0,1283^{* * *}$ & $<0,0001$ \\
\hline Árbevétel/eszközök12_l & 0,0111 & 0,4949 \\
\hline Árbevétel/eszközök11 & $0,0870 * * *$ & 0,0011 \\
\hline Árbevétel/eszközök11_l & $-0,0665^{* *}$ & 0,0227 \\
\hline Árbevétel/eszközök10 & $0,0651^{*}$ & 0,0541 \\
\hline Árbevétel/eszközök10_1 & $-0,0009$ & 0,9706 \\
\hline Árbevétel/eszközök09 & $0,0715^{* * *}$ & 0,0038 \\
\hline Árbevétel/eszközök09_1 & $-0,0003$ & 0,9908 \\
\hline Árbevétel/eszközök08 & $0,0360 *$ & 0,0638 \\
\hline Árbevétel/eszközök08_1 & 0,0018 & 0,9017 \\
\hline Árbevétel/eszközök07_l & 0,0197 & 0,1708 \\
\hline Szállitók aránya14 & $-0,1216^{*}$ & 0,0808 \\
\hline Szállitók aránya13 & $-0,1107 * * *$ & 0,0003 \\
\hline Szállitók aránya12 & $-0,1277 * * *$ & $<0,0001$ \\
\hline Szállitók aránya11 & $-0,1192 * * *$ & 0,0002 \\
\hline Szállitók aránya 10 & $-0,0523$ & 0,1831 \\
\hline Szállitók aránya09 & $-0,0739 * *$ & 0,0279 \\
\hline Szállitók aránya08 & $-0,1112^{* * *}$ & 0,0025 \\
\hline
\end{tabular}

(A táblázat folytatása a következő oldalon.) 
(Folytatás.)

\begin{tabular}{|c|c|c|}
\hline \multirow{2}{*}{ Magyarázó változó } & \multicolumn{2}{|c|}{ LSDV $R^{2}=0,6966$} \\
\hline & Együttható & $p$-érték \\
\hline SzJR-arány14 & 0,0239 & 0,6340 \\
\hline SzJR-arány 13 & 0,0400 & 0,4330 \\
\hline SzJR-arány 12 & 0,0152 & 0,7596 \\
\hline SzJR-arány11 & 0,0588 & 0,2713 \\
\hline SzJR-arány 10 & $0,1509^{* * *}$ & 0,0055 \\
\hline SzJR-arány09 & 0,0445 & 0,4356 \\
\hline SzJR-arány08 & $0,1264 * *$ & 0,0194 \\
\hline Egyéb bevételek arányal4 & 0,1566 & 0,1873 \\
\hline Egyéb bevételek aránya13 & $0,1571 * * *$ & 0,0057 \\
\hline Egyéb bevételek aránya12 & $0,2040^{* * *}$ & $<0,0001$ \\
\hline Egyéb bevételek arányal1 & $0,2307 * * *$ & $<0,0001$ \\
\hline Egyéb bevételek aránya10 & $0,1144^{*}$ & 0,0669 \\
\hline Egyéb bevételek aránya09 & 0,0517 & 0,4121 \\
\hline Egyéb bevételek aránya08 & 0,0982 & 0,1087 \\
\hline $\log ($ Likviditási ráta $) 14$ & 1,2919 & 0,2061 \\
\hline $\log ($ Likviditási ráta) 13 & $1,8340 * *$ & 0,0436 \\
\hline log(Likviditási ráta)13_1 & $-1,5612$ & 0,1436 \\
\hline $\log ($ Likviditási ráta $) 12$ & $2,4926^{* *}$ & 0,0188 \\
\hline $\log \left(\right.$ Likviditási ráta) $12 \_1$ & $-1,6748^{*}$ & 0,0754 \\
\hline $\log ($ Likviditási ráta $) 11$ & $3,8476^{* * *}$ & $<0,0001$ \\
\hline $\log \left(\right.$ Likviditási ráta) $11 \_1$ & $-1,7999$ & 0,1034 \\
\hline $\log ($ Likviditási ráta $) 10$ & $-0,3341$ & 0,7997 \\
\hline log(Likviditási ráta)10_1 & $-3,4749 * * *$ & $<0,0001$ \\
\hline $\log ($ Likviditási ráta)09 & 0,9141 & 0,3480 \\
\hline log(Likviditási ráta)09_1 & $-0,5858$ & 0,6606 \\
\hline $\log ($ Likviditási ráta $) 08$ & $2,5547 * * *$ & 0,0074 \\
\hline $\log \left(\right.$ Likviditási ráta) $08 \_1$ & $-1,4089$ & 0,1686 \\
\hline $\log ($ Likviditási ráta)07_1 & $-2,0179 * *$ & 0,0236 \\
\hline
\end{tabular}

(A táblázat folytatása a következö oldalon.) 
(Folytatás.)

\begin{tabular}{|c|c|c|}
\hline \multirow{2}{*}{ Magyarázó változó } & \multicolumn{2}{|c|}{ LSDV $R^{2}=0,6966$} \\
\hline & Együttható & $p$-érték \\
\hline sq_Idegen töke arányal4 & $-0,0020 * *$ & 0,0124 \\
\hline sq_Idegen töke arányal3 & $-0,0015 * *$ & 0,0437 \\
\hline sq_Idegen töke arányal3_l & $0,0026^{* * * *}$ & 0,0096 \\
\hline sq_Idegen töke arányal2 & $-6,2983 e-05$ & 0,9634 \\
\hline sq_Idegen töke arányal2_l & $0,0022^{* * * *}$ & 0,0098 \\
\hline sq_Idegen töke arányal1 & $-0,0021 * * *$ & 0,0045 \\
\hline sq_Idegen töke arányal1_1 & 0,0007 & 0,6061 \\
\hline sq_Idegen töke arányalo & $-0,0034 * * *$ & 0,0029 \\
\hline sq_Idegen töke aránya10_1 & $0,0021 * * *$ & 0,0013 \\
\hline sq_Idegen töke aránya09 & $-0,0030 * * *$ & 0,0026 \\
\hline sq_Idegen töke aránya09_1 & $0,0046^{* * *}$ & $<0,0001$ \\
\hline sq_Idegen töke aránya08 & $-0,0034 * * *$ & 0,0002 \\
\hline sq_Idegen töke aránya08_1 & $0,0032 * * *$ & 0,0002 \\
\hline sq_Idegen töke aránya07_1 & $0,0037 * * *$ & $<0,0001$ \\
\hline
\end{tabular}

Megjegyzés. LSDV (least squares dummy variables estimator): fix hatású panelbecslés dummy változó(k) bevonásával; SzJR: személyi jellegü ráfordítások. A változók nevei után közvetlenül szereplő számok évekre, míg az ,_1"-ek késleltetett hatásokra utalnak. *** $p<0,01 ; * * p<0,05 ; * p<0,1$.

Forrás: Saját számítás a Gretl for Windows program segítségével.

\section{Irodalom}

Al-JAFARI, M. K. - Al SAmman, H. [2015]: Determinants of profitability: evidence from industrial companies listed on muscat securities market. Review of European Studies. Vol. 7. No. 11. pp. 303-311. http://dx.doi.org/10.5539/res.v7n11p303

BAIN, J. S. [1956]: Barriers to New Competition. Harvard University Press. Cambridge.

BAIN, J. S. [1968]: Industrial Organization. (2 ${ }^{\text {nd }}$ Edition.) John Wiley \& Sons. Hoboken.

BARNEY, J. [1991]: Firm resources and sustained competitive advantage. Journal of Management. Vol. 17. Issue 1. pp. 99-120. http://dx.doi.org/10.1177/014920639101700108

Carlton, D. W. - Perloff, J. M. [2006]: Modern piacelmélet. Panem Kft. Budapest.

CHAdDAD, F. R. - Mondelli, M. P. [2013]: Sources of firm performance differences in the US food economy. Journal of Agricultural Economics. Vol. 64. No. 2. pp. 382-404. https://doi.org/10.1111/j.1477-9552.2012.00369.x

Chander, S. - Aggarwal, P. [2008]: Determinants of corporate profitability: an empirical study of Indian drugs and pharmaceutical industry. Paradigm. Vol. 12. Issue 2. pp. 51-61. http://journals.sagepub.com/doi/abs/10.1177/0971890720080206

Dencic-Minajlov, K. [2014]: Profitability during the financial crisis: evidence from the regulated capital market in Serbia. South-Eastern Europe Journal of Economics. Vol. 12. No. 1. pp. 7-33. https://ojs.lib.uom.gr/index.php/seeje/article/view/5507 
DoĞAN, M. [2013]: Does firm size affect the firm profitability? Evidence from Turkey. Research Journal of Finance and Accounting. Vol. 4. No. 4. pp. 53-59.

EDWARDS, S. - AllEN, A. J. - SHAIK, S. - HARRIS, J. [2009]: Market structure conduct performance (SCP) hypothesis revisited using stochastic frontier efficiency analysis. Journal of the Transportation Research Forum. Vol. 48. No. 3. pp. 5-18. http://dx.doi.org/10.5399/osu/jtrf.48.3.2311

Fareed, Z. - Ali, Z. - ShahZAd, F. - NAZiR, M. I. - Ullah, A. [2016]: Determinants of profitability: evidence from power and energy sector. Studia Universitatis Babes-Bolyai Oeconomica. Vol. 61. Issue 3. pp. 59-78. https://doi.org/10.1515/subboec-2016-0005

GSCHWANDTNER, A. [2012]: Evolution of profit persistence in the USA: evidence from three periods. The Manchester School. Vol. 80. Issue 2. pp. 172-209. http://dx.doi.org/10.1111 /j.1467-9957.2011.02277.x

Hirsch, S. - Gschwandtner, A. [2013]: Profit persistence in the food industry: evidence from five European countries. European Review of Agricultural Economics. Vol. 40. Issue 5. pp. 741-759. https://doi.org/10.1093/erae/jbt007

Hirsch, S. - Hartmann, M. [2014]: Persistence of firm-level profitability in the European dairy processing industry. Agricultural Economics. Vol. 45. Issue S1. pp. 53-63. https://doi.org/10.1111/agec.12129

HIRSCH, S. - SCHIEFER, J. [2016]: What causes firm profitability variation in the EU food industry? A redux of classical approaches of variance decomposition. Agribusiness. Vol. 32. Issue 1. pp. 79-92. https://doi.org/10.1002/agr.21430

KEMÉNY G. [2010]: A hazai mezőgazdaság finanszírozásának főbb elemei a pénzügyi válságban. Gazdálkodás. 54. évf. 5. sz. 479-487. old.

LAZĂR, S. [2016]: Determinants of firm performance: evidence from Romanian listed companies. Review of Economic and Business Studies. Vol. 9. Issue 1. pp. 53-69. https://doi.org/10.1515/rebs-2016-0025

Nunes, P. J. M. - Serrasqueiro, Z. M. - Sequeira, T. N. [2009]: Profitability in Portuguese service industries: a panel data approach. The Service Industries Journal. Vol. 29. Issue 5. pp. 693-707. https://doi.org/10.1080/02642060902720188

PANTEA, M. - Gligor, D. - ANIS, C. [2014]: Economic determinants of Romanian firms' financial performance. Procedia - Social and Behavioral Sciences. Vol. 124. 20 March. pp. 272-281. https://doi.org/10.1016/j.sbspro.2014.02.486

Pervan, M. - MLikota, M. [2013]: What determines the profitability of companies: case of Croatian food and beverage industry. Economic Research-Ekonomska Istraživanja. Vol. 26. Issue 1. pp. 277-286. https://doi.org/10.1080/1331677X.2013.11517602

PorTER, M. E. [1979]: The structure within industries and companies' performance. The Review of Economics and Statistics. Vol. 61. No. 2. pp. 214-227. https://doi.org/10.2307/1924589

PORTER, M. E. [1981]: The contributions of industrial organization to strategic management. The Academy of Management Review. Vol. 6. No. 4. pp. 609-620. https://doi.org/10.2307/ 257639

PRATHeEPAN, T. [2014]: A panel data analysis of profitability determinants: empirical results from Sri Lankan manufacturing companies. International Journal of Economics, Commerce and Management. Vol. 11. Issue 12. pp. 1-9. 
Rumelt, R. P. [1991]: How much does industry matter? Strategic Management Journal. Vol. 12. No. 3. pp. 167-185. https://doi.org/10.1002/smj.4250120302

SChiefer, J. - Hartmann, M. [2009]: Industry, Firm, Year, and Country Effects on Profitability: Evidence from a Large Sample of EU Food Processing Firms. Agricultural and Applied Economics Association, Afghanistan Chamber of Commerce and Industries. Joint Annual Meeting. 26-29 July. Milwaukee. https://ageconsearch.umn.edu/bitstream/49322/1/609646.pdf

Schmalensee, R. [1985]: Do markets differ much? The American Economic Review. Vol. 75. No. 3. pp. 341-351.

YAZDANFAR, D. [2013]: Profitability determinants among micro firms: evidence from Swedish data. International Journal of Managerial Finance. Vol. 9. Issue 2. pp. 151-160. https://doi.org/10.1108/17439131311307565

ZouAGHI, F. - HiRsch, S. - Garcia, M. S. [2016]: What makes firms profitable? A multilevel approach to the Spanish agri-food sector. In: New Dimensions of Market Power and Bargaining in the Agri-food Sector: Organisations, Policies and Models. The $153^{\text {th }}$ European Association of Agricultural Economists Seminar. 9-10. June. Gaeta.

\section{Summary}

The aim of the study is to introduce how profitability of the Hungarian agricultural companies can be described by financial indicators, to suggest a new approach for the measurement and selection of such indicators as well as to estimate and test their effects based on panel data. The structural break in panel data makes the tracking of the time-variant effects of regressors possible. Modelling of ROA (return on assets), the indicator of profitability supports the conclusion that profitability can be increased by a structural shift towards current assets on the asset-side of the balance sheet, efficient utilization of assets and, in the long run, by the introduction of foreign capital into the financial structure. Certain regressors have an effect on profitability through their lags. The study presents a new approach: the most relevant variables from a full model built on economic hypotheses are selected by taking the professional relevance of regressors into account instead of applying an automatic algorithm. The structurally broken quadratic and logarithmic effects are also present in the final model. The study proposes a new panel approach to select the regressors to be applied. 